\title{
KEELERESSURSSIDE LITSENTSIMISE ÕIGUSLIKKE KÜSIMUSI
}

\author{
Kadri Vider, Heiki Pisuke, Peeter P. Mõtsküla, \\ Triin Tuulik, Aleksei Kelli
}

\begin{abstract}
Ülevaade. Artikkel käsitleb teaduspoliitilisi ja õiguslikke küsimusi, mida tuleks arvestada keeleressursside litsentsimisel, ja määratleb sobivaimad litsentsimise tingimused, pöörates tähelepanu eelkõige lepinguõiguse ja intellektuaalomandi litsentsimise küsimustele. Samuti võrreldakse artiklis USA, Euroopa riikide ja Eesti keeleressursside litsentsimise õiguslikku raamistikku ning tutvustatakse levinumaid praktikaid avatud juurdepääsu (ingl open access) ja vabade (avatud) litsentside vaatepunktist. Artikli praktiliseks eesmärgiks on selgitada Eestis keeleressursside loomise ja kasutamisega seotud teadlastele ja teadusasutustele intellektuaalomandi (IO) objektide litsentsimise põhialuseid ja jagada näpunäiteid litsentsitingimuste valimiseks. Artikkel on sündinud keeleteadlaste ja juristide koostöös ning mõeldud esmajoones keeleteadlastest lugejaskonnale. ${ }^{*}$
\end{abstract}

Võtmesõnad: keeleressursid, keeletehnoloogia, intellektuaalomand, autoriõigus, litsentsimine, avatud juurdepääs, META-SHARE, CLARIN

\section{Sissejuhatus}

Keeleuuringute ja keeletehnoloogia edukaks arendamiseks on vaja hulgaliselt keelelist lähtematerjali. Uuringute käigus lähtematerjali töödeldakse ja analüüsitakse ning selle tulemusena valmivad ka mitmesugused digitaalsed keeleressursid. Neid ressursse võidakse kasutada uutes teadusuuringutes, kuid nad võivad leida rakendust muudeski avalikes huvides ning olla sisendiks uute toodete ja teenuste väljatöötamisel erasektoris. Sellise lähtematerjali ja loodud digitaalsete keeleressursside kasutamise üheks teaduspoliitiliseks ja õiguslikuks nurgakiviks on autoriõigusest tulenevad erandid ja litsentsilepingud. 
Problemaatilisemad keeleressursid on õiguslikus tähenduses andmebaasid. Selliste andmebaaside loomisel ja kasutamisel kerkivad mitmed keerulised õiguslikud küsimused seoses autoriõiguse ja sellega kaasnevate õigustega.

Eestis ja Euroopas on mitmed laiahaardelised algatused keeleressursside loomiseks ja laialdaselt kättesaadavaks tegemiseks, näiteks META-NET ja CLARIN, mille raames on loodud ka keeleressursside tüüplitsentse. Nii META-SHAREi hartas ${ }^{1}$ kui ka CLARIN ERICu põhikirjas ${ }^{2}$ rõhutatakse avatud juurdepääsu ja avatud lähtekoodi põhimõtete järgimise olulisust. Autorid selgitavad, mida avatud juurdepääs keeleressursside litsentsimisel tähendab ja mille poolest vastavad tüüplitsentsid omavahel erinevad.

\section{Keeleressursid ja nende litsentsimise vajadus}

Lingvistide ja keeletehnoloogide vaatenurgast jagunevad digitaalsed keeleressursid iseloomu poolest kaheks: keeleteaduslikuks andmestikuks ja tarkvaraks.

1) Keeleteaduslik andmestik:

a) korpused (tekstilised või helilised/pildilised keelematerjali sisaldavad ja elavat keelekasutust esindavad kogumid) - nende probleemistikuga on siiani kõige rohkem tegeldud (Kelli jt 2012: 40-48, Tavast jt 2013 siinses kogumikus), sest sisaldavad juba loodud tekste ja kõneldud keelt, mis on sageli autoriõiguse objektiks;

b) leksikonid ehk sõnavara kogumid;

c) keelemudelid (näiteks puudepank).

2) Tarkvara, mis midagi keeleandmestikuga teeb, seda suuremal või vähemal määral töötleb ja muudab (näiteks annoteerib, loob sisendfaile järgmise masintöötluse etapi jaoks, loob väljundit lõppkasutaja jaoks, olgu lõppkasutajaks IT-süsteem või inimene):

d) iseseisvad programmid või lausa infotehnoloogilised terviksüsteemid;

e) tarkvarajupid või teegid, mida ühendatakse umbes nagu legoklotse erinevaid ülesandeid täitvateks struktuurideks.

Keeleressursside loojal võib tekkida küsimus, miks on litsentsimine vajalik? Seni on ju keeleteadlased suhteliselt muretult kasutanud digitaalselt saadaolevaid keeleressursse oma teadustöös andmestiku või tehnoloogiana. Keeleteadlase jaoks on andmestiku puhul erinevus ainult meediumis, mis on muutunud digitaalseks ja saanud juurde ohtralt analüüsiprotsessi abistavat tarkvara. Seinatäis kartoteegikaste erinevatest allikatest välja kirjutatud sedelitega oli eelmise põlvkonna tekstikorpus, keelejuhtide salvestised erinevatelt murdealadelt aga kõnekorpus. Kordades rohkem aega võttis toona teadlast huvitava keelematerjali ülesleidmine, andmete hulk oli väiksem ja analüüs aeglasem, sest kõikide keeletasandite analüüs tuli teha käsitsi ja paberi peal. Umbes 1995. aastast alates on eesti keeleteadlased aga harjunud üha enam ja enam kasutama digitaalselt saadaolevaid keeleandmestikke ja analüüsitarkvara, õppinud koostama üha keerulisemaid päringuid huvipakkuva ainese korjamiseks kogu digimaailmas leiduva keelematerjali pealt.

Euroopa Komisjoni rahastatud tippteadmiste võrgustiku META-NET läbiviidud keeleressursside ja -tehnoloogiate alasest uurimusest (Liin jt 2012) selgus, et 
enamikku Euroopa keeltest ootab ees “digitaalne hääbumine”. Eksperdid leidsid, et vahe "suurte" ja "väikeste" keelte vahel üha kasvab ning väiksematele ja vähemate ressurssidega keeltele tuleb digitaalse väljasuremise ennetamiseks tagada esmatähtsad baastehnoloogiad. ${ }^{3}$ Ka eesti keel paigutub META-NETi uuringus ohustatud keelte hulka. ${ }^{4}$ Arvestades eesti keele- ja kultuuriruumi väiksust on see mõistetav, sest eestikeelse kõnelejaskonnaga sihtturg ei paku ettevõtjatele nii avaraid ärilisi võimalusi nagu ulatuslikuma kasutajaskonnaga keelte puhul. Enamikul maailma rahvastikust pole huvi tagada eesti keele digitaalset kestmajäämist ega lootust teenida maailma mõistes arvestatavat kasumit, varustades eesti keele toega eri seadmeid ja tarkvara. Riiklikud investeeringud keeleressursside ja -tehnoloogiate loomiseks, arendamiseks ning kättesaadavaks tegemiseks on üks otsesemaid viise, kuidas seda turutõket ületada ${ }^{5}$.

Eestis on keeletehnoloogilise toe vajadust teadvustatud riiklikus eesti keele arengukavas, mille mõjul on juba alates 2006. aastast keeletehnoloogia riiklike programmide kaudu rahastatud valdkondlikku teadus- ja arendustegevust (Liin jt 2012: 25).

Keeleressursse luuaksegi Eestis praegu peamiselt riikliku teadus- ja arendustegevuse raames (Liin jt 2012: 25). Eesti Keeleressursside Keskus (EKRK) on kutsutud ja seatud hoolitsema selle eest, et riiklike keeletehnoloogia teadusprogrammide tulemused ei jääks hajutatult ripakile, vaid oleks kättesaadavad ja kasutatavad ühes raamistikus erinevatele huviliste rühmadele ja selgelt sõnastatud tingimustel. Tingimuste hulka kuuluvad iga keeleressursi kasutamisega kaasnevad õigused ja kohustused. Nende õiguste ja kohustuste raames keeleressursside kasutada andmist nimetataksegi litsentsimiseks (VõS § 368). Kuigi programmides on üldisemalt sõnastatud Eesti riigi raha eest tehtava teadus- ja arendustöö tulemuste intellektuaalomandi kuuluvus ${ }^{6}$ ja levitamise poliitika ${ }^{7}$, ei piisa sellest iga üksiku keeleressursi kasutusse andmiseks maailmas, kus tehnoloogia kiire arengu taustal on keeleressursside kasutamise vastu huvi mitte ainult teadlastel, vaid ka laiemal avalikkusel ja kasumitaotlusega erasektoril. Selged kasutustingimused litsentsi näol on vajalikud ka ressursside loojatele, kes saavad selle kaudu väljendada oma soove, kuidas nende loomingut tohib kasutada.

Nii nagu muud riigi toel loodud teadustulemused, on ka keeleressursid oma olemuselt avalik hüve. Seega peaks nende loomine, arendamine ja levitamine alluma samadele poliitikakaalutlustele nagu teiste teadustulemuste levitamine. Et vältida olukorda, kus keeleressursid on vaid kitsa teadlaskogukonna uurimisobjekt, tuleks kehtestada poliitika, mis lubab nende kättesaadavaks tegemist ja kasutamist ka laiema avalikkuse poolt. Sellisel juhul tekib paratamatult küsimus, kas riiklikest vahenditest rahastatud keeleressursid peaks jääma kasutamiseks ainult avalikes huvides või tohib neid rakendada ka ärilistel eesmärkidel, näiteks uute toodete ja teenuste arendamiseks ja müügiks.

3 META-NET. Vähemalt 21 Euroopa keelt on digihääbumise ohus. META-NET Valge raamatu sari: Pressiteade, 20.09.2012. Vt http://www.meta-net.eu/whitepapers/press-release-et (23.09.2012).

4 lbid.

5 Käesolevas artiklis ei käsitleta tarbijakaitseõiguse küsimusi, millest tuleneb kohustus teatud juhtudel anda toote ja 


\section{Avatud juurdepääs}

Eestis ei ole hetkel kehtestatud ühtset avatud juurdepääsu (ingl open access) poliitikat teadusasutustes ega riiklikul tasemel. Samas on see teema aktuaalne teadus- ja innovatsioonipoliitika seire programmis, mis on sisendiks haridus- ja teadusministeeriumile vastava poliitika kujundamisel. ${ }^{8}$ Eesti juhtivatel ülikoolidel on küll olemas intellektuaalomandi käsitlemise dokumendid ${ }^{9}$, kuid need käsitlevad peamiselt töötajate ja ülikooli vahelist kokkulepet töötaja intellektuaalomandi õiguste üleminekuks ning kasutamiseks ülikooli, mitte aga avalikkuse poolt. Sellele on juba tähelepanu juhitud erialakirjanduses ning tehtud ettepanek kehtestada ülikoolides loodud intellektuaalomandi kasutamise ühtsed riiklikud põhimõtted ning edendada avatud litsentsimise poliitikat (Pisuke, Kelli 2007: 171).

Avatud juurdepääs ei ole õiguslik mõiste (Tuulik 2012). Nagu nimetuski viitab, tähendab see teatud õiguslike ja administratiivsete tõkete kõrvaldamist. Siin peetakse esmajoones silmas kasutuspiiranguid, mis tulenevad autoriõigusest. Näiteks on autoriõiguse üldpõhimõteteks, et teose õiguspäraseks kasutamiseks peab olema autori nõusolek, tuleb maksta autoritasu, teost ei tohi autori nõusolekuta muuta ja autorile tuleb alati viidata. Vaid autor või autoriõiguste omaja (tööandja, teose lepingu alusel kasutaja, pärija vms) saab otsustada, kas lubada avatud juurdepääsu, andes selleks oma teose kasutamiseks vastava loa ehk litsentsi. Kaudselt edendatakse avatud juurdepääsu võimaldamist ka poliitiliste vahenditega, kehtestades vastavaid rahastamis- ja publitseerimispõhimõtteid või korraldades üldharivaid kampaaniaid. Näiteks riiklikus teadus- ja arendustegevuse programmis "Eesti keele tehnoloogia 2011-2017"10 on loodavate keeleressursside ja tarkvara litsentsimise põhimõtete seas välja toodud, et eelistatakse avatud juurdepääsuga litsentsimist.

Avatud juurdepääsu mõiste on kasutusel nii kitsas kui ka laias tähenduses. Kitsamalt tähendab see näiteks eelretsenseeritavate teadustulemuste tasuta kättesaadavaks tegemist internetis.

Laiemas tähenduses ei ole avatud juurdepääs piiratud ainult teadustulemuste kättesaadavaks tegemisega internetis. Juba 1980. aastate alguses tekkis nn vaba tarkvara liikumine ning võeti kasutusele vaba tarkvara (ingl free software) mõiste. Vaba tarkvaraga on tegemist, kui kasutajale on tagatud neli põhivabadust: vabadus programmi mistahes eesmärgil kasutada, seda uurida ja muuta ning programmi ennast ja selle modifikatsioone levitada. ${ }^{11}$ 1990ndate lõpus arenes selle kõrval välja avatud lähtekoodiga tarkvara (ingl open source software) mõiste. ${ }^{12}$ Kuigi "vaba tarkvara" ja "avatud lähtekoodiga tarkvara" ideoloogiline taust on vägagi erinev, kasutatakse neid sageli sünonüümidena. ${ }^{13}$ Hiljem hakati neid lisaks tarkvarale laiendama ka muudele teose liikidele ning tänaseks on välja pakutud mitmeid

\footnotetext{
8 Eestis on valminud teadus- ja innovatsioonipoliitika seire programmi raames vastav analüüs koos poliitikasoovitustega. - Aleksei Kelli, Tõnis Mets, Merit Burenkov. Autoriõiguse ning avatud juurdepääsu (open access) küsimused teadus- ja arendustegevuses. Vt http://www.tips.ut.ee/index.php?module=32\&op=1\&id=3527 (21.12.2012).

9 Vt nt Tartu Ülikool. Intellektuaalse omandi käsitlemise põhimõtted Tartu Ülikoolis. KINNITATUD Tartu Ülikooli nõukogu 18. novembri 2003. a määrusega nr 17 (jõustunud 28.11.2003). Muudetud Tartu Ülikooli nõukogu 19. detsembri 2008. aasta määrusega nr 25 (jõustunud 29.12.2008) - vt http://www.ut.ee/sites/default/files/livelink files/intellektuaalse omandi ksitlemise phimtted tartu likoolis terviktekst.pdf (23.09.2012); Tallinna Ülikool. Intellektuaalse omandi õiguskaitse eeskiri Tallinna Ülikoolis. KEHTESTATUD TPÜ nõukogu 14.06.2004. a määrusega nr 9 - vt http://www.tlu.ee/files/arts/314/intel2e2435b4d99b60a2481cd7c54d2f93a7.pdf (23.09.2012).

10 Kinnitatud haridus- ja teadusministri 25. jaanuari 2011. a käskkirjaga nr 71; allalaetav http://www.keeletehnoloogia.ee/EKT2011-2017-programm-uuendet.pdf (14.12.2012).

11 Free Software Definition. Free Software Foundation. Vt http://www.gnu.org/philosophy/free-sw.html (14.12.2012).

12 http://opensource.org (14.12.2012).

13 Vt nt E. S. Raymond. Goodbye, "free software"; hello, "open source", http://www.catb.org/ esr/open-source.html (21.12.2012) ja R. Stallman. Why Open Source misses the point of Free Software, http://www.gnu.org/philosophy/ open-source-misses-the-point.html (21.12.2012).
} 
erinevaid avatud juurdepääsu määratlusi sõltumata objektist, mida selle mõistega kirjeldatakse. ${ }^{14}$ Seni puudub aga üksmeel selle osas, milline määratlus on domineeriv. Kuna puudub selge kokkulepe, kui vähe piiranguid on võimalik avatud juurdepääsu litsentsiga kehtestada, tutvustavad autorid lühidalt erinevaid lähenemisviise.

Hetkel on kasutusel rohkem kui 100 infotehnoloogia valdkonnas tunnustatud vaba tarkvara litsentsi. ${ }^{15}$ Neist kõige tuntum on Richard M. Stallman'i poolt 1989. aastal kirjutatud ning hiljem kahel korral uuendatud GNU ${ }^{16}$ üldine avalik litsents (GNU General Public License ehk GPL). Selle erinevaid versioone kasutatakse hinnanguliselt rohkem kui pooltes kõigist vaba tarkvara projektidest (Mõtsküla 2009: 19). Kuigi GPLi alusel võib litsentsida mistahes teoseid, mille "lähtekood" on selgelt määratletav ${ }^{17}$, sobib see, nagu ka muud vaba tarkvara litsentsid, ennekõike arvutiprogrammide litsentsimiseks.

Lihtsustamaks vaba tarkvara põhimõtete rakendamist muudele teostele, asutati professor Lawrence Lessigi juhtimisel 2001. aastal mittetulundusühing Creative Commons $^{18}$ (CC), mis avaldas 2002. aastal esimese litsentside komplekti, mis sobib väga laiale teosteringile. Siiski ei soovita CC oma litsentse kasutada arvutiprogrammide litsentsimiseks. ${ }^{19}$ Andmebaaside puhul on CC litsentsid kasutatavad niivõrd, kuivõrd andmebaas on kaitstud autoriõigusega. Euroopa Liidu õigusest tulenevaid andmebaasi tegija iseseisvaid ehk sui generis õiguseid ${ }^{20} \mathrm{CC}$ litsentside kehtivais versioonides ei puudutata. Kuid järgmises, praegu väljatöötamisel olevas versioonis (4.0), võib see muutuda ja CC litsentse saaks sellisel juhul kasutada ka sui generis õiguste litsentsimiseks. ${ }^{21}$ Erandiks on siinkohal CC Zero (CCo $)^{22}$, mis on kasutatav nii lähtekoodi, andmebaaside kui ka mistahes muude teoste andmiseks avalikku kasutusse. Sellist kõigile isikutele vaba kasutamist nimetatakse üldsusele avatud kasutamiseks (ingl public domain). Hiljem on CC oma litsentse korduvalt täiustanud ning kohandanud rohkem kui 50 riigi õigussüsteemi jaoks. ${ }^{23}$ Tänaseks on CC litsentsisüsteem kujunemas avatud sisu rahvusvaheliselt tunnustatud litsentsistandardiks (Kreutzer 2011: 135).

Nähes, et ei vaba tarkvara ega muud avatud sisu litsentsid ei ole optimaalselt kohaldatavad andmebaasidele, käivitas Jordan Hatcher 2007. aastal projekti Open Data Commons (ODC) ${ }^{24}$, mille eesmärk oli töötada välja vabad (avatud) andmebaasilitsentsid. Alates 2009. aastast tegutseb ODC Open Knowledge Foundation’i egiidi all. ODC projekt pakub uudse lahendusena välja "soovituslike tingimustega vabakasutuse". Nimelt annab ODC avalikku kasutusse andmise avaldus ja litsents (Public Domain Dedication and License, PDDL) ${ }^{25}$ selle kasutajale võimaluse viidata heale tavale, mis on sätestatud ODC kogukonna normides. ${ }^{26}$ Need normid ei oma

\footnotetext{
14 Open Knowledge Foundation'i Open Definition (http://opendefinition.org, 21.12.2012) ning Vabade Kultuuriliste Teoste Definitsioon (Definition of Free Cultural Works, http://freedomdefined.org, 21.12.2012), mida tunnustab ka mittetulundusühing Creative Commons (CC) (http://creativecommons.org/weblog/entry/8051, 21.12.2012).

$15 \mathrm{Vt}$ http://www.gnu.org/licenses/license-list.html (21.12.2012) ja http://opensource.org/licenses (21.12.2012).

16 GNU (GNU's Not Unix, rekursiivne lühend) on täielikult vabast tarkvarast koosnev UNIXi-laadne operatsioonisüsteem.

17 Frequently Asked Questions about the GNU Licenses. Free Software Foundation. http://www.gnu.org/licenses/ gpl-faq.html\#GPLOtherThanSoftware (21.12.2012).

18 Creative Commons http://creativecommons.org (21.12.2012).

19 Vt http://wiki.creativecommons.org/FAQ\#Can I apply a Creative Commons license to software.3F (21.12.2012).

20 Sui generis andmebaaside olemust käsitletakse punktis 4.1.

$21 \mathrm{Vt}$ http://wiki.creativecommons.org/FAQ\#Can_I apply_a_Creative_Commons license to data_or_a_database.3F

(21.12.2012).

${ }^{22} \mathrm{Vt}$ http://creativecommons.org/choose/zero/ (21.12.2012).

${ }^{23}$ CC litsentside versiooni 3.0 eestikeelsed ja Eesti õigusele kohandatud variandid avaldati 2010. aasta oktoobris. Vt http://creativecommons.ee (21.12.2012).

24 Vt http://opendatacommons.org (21.12.2012).

$25 \mathrm{Vt}$ http://opendatacommons.org/licenses/pddl/ (21.12.2012).

$26 \mathrm{Vt}$ http://opendatacommons.org/norms/odc-by-sa/ (21.12.2012).
} 
iseseisvat õiguslikku sisu ning nad on soovituslikud vaid nende teoste kasutajate suhtes, mis on vabasse kasutusse antud PDDL alusel ning mille vabasse kasutusse andja on kogukonna normidele viidanud.

Eelpool käsitletud litsentside puhul on tegemist nn kasutuskogukonna normidega, mida kohaldavad omavahel selle kogukonna liikmed või isikud, kes on nõus neid soovitusi teatud tüüptingimustena vabatahtlikult järgima. Kogukonnad võivad anda oma liikmetele soovitusi selle osas, milliseid litsentse kasutada (või isegi seada teatava litsentsi kasutamine kogukonna ühisvaramusse panustamise eeltingimuseks, nt Wikipedia). Siiski on GPL, ODC-ODbL (Open Data Commons Open Database License ${ }^{27}$ ja CC litsentsid, juhul kui autor on oma teose nende alusel avalikkusele litsentsinud, teoste kasutajate jaoks õiguslikult siduvad (kui kasutaja just ei võta vaevaks autorilt endale eritingimusi välja kaubelda). Seda kinnitab asjaolu, et Saksa kohtutes on GPL litsentside tingimusi korduvalt jõustatud (Mõtsküla 2009: 46-47). Kui näiteks CC litsentsi kasutustingimustega nõustumine ja teatud litsentsitüübi kasutamine ei oleks isikule õiguslikult siduv, siis ei saaks me rääkida ühiskonna õiguskindlusest, kui iga hetk võiks oma lubadust tagasi võtta.

Vaba ja avatud tarkvara liikumine sai alguse Ameerika Ühendriikidest. USA õigussüsteem, õigusteooria ja -praktika erinevad väga suurel määral kontinentaalEuroopa riikide tsiviilõigusel põhinevast tavast. ${ }^{28}$ Erinevad on õigusdoktriinid ja isegi lepinguõiguses kasutatav terminoloogia. Nende probleemide ületamiseks töötati Euroopa Liidu (EL) Komisjoni otsesel initsiatiivil välja Euroopa Liidu tarkvara vaba kasutuse litsents (European Union Public License, EUPL), mis avaldati 2007. aastal. EUPL põhineb suures ulatuses Euroopas kasutusel olevatel litsentsidel ning kasutab Euroopa õigussüsteemile omast mõisteaparaati ja terminoloogiat. Oluline uudne lähenemine oli ka see, et nimetatud litsents tõlgiti ja toimetati EL Komisjoni initsiatiivil vastavaks kõigi EL ametlike keelte õigussüsteemidega, sealhulgas eesti keeles Eesti õigussüsteemiga. ${ }^{29}$ Kuigi see litsents on välja töötatud konkreetselt tarkvara kasutust silmas pidades, väärib see erilist tähelepanu kui võimalik eeskuju muude teose liikide kasutamiseks.

Avatud juurdepääsu põhimõtteid on püütud määratleda ka teistes dokumentides ja initsiatiivides. ${ }^{30}$

Arvestades erinevaid välja pakutud avatud juurdepääsu käsitlusi ja tüüplitsentside tingimusi, on autorid seisukohal, et avatud juurdepääsuga laias tähenduses on tegemist siis, kui autor on andnud litsentsilepingu alusel kasutajale õiguse teost mistahes eesmärgil (sh nii isiklikul otstarbel, avalikes huvides kui ka ärilistel eesmärkidel) kasutada ja taaskasutada, uurida ja modifitseerida ning reprodutseerida ja levitada, kusjuures nende õiguste teostamine on piiratud ainult kohustusega viidata algsele autorile.

\footnotetext{
27 Vt http://opendatacommons.org/licenses/odbl/ (23.02.2013)

28 Euroopas on USAga samas õigusperekonnas Ühendkuningriik ja lirimaa, mille õigus põhineb niinimetatud üldise õiguse (Common Law) traditsioonidel.

${ }_{29}$ Euroopa Liidu tarkvara vaba kasutuse litsents (1.0) http://ec.europa.eu/idabc/servlets/Doc3cb1.pdf?id=29923 (22.12.2012); vt ka European Union Public Licence - EUPL v.1.1 http://ec.europa.eu/idabc/en/document/7774.html (23.12.2012).

30 UNESCO. Open Access to scientific information: Policy guidelines released. 06.04.2012 - vt http://www.unesco. org/new/en/communication-and-information/resources/news-and-in-focus-articles/all-news/news/open access to scientific information policy guidelines for_open_access released/ (23.09.2012); Bethesda Statement on Open Access Publishing. Released 20.06.2003 - vt http://www.earlham.edu/ peters/fos/bethesda.htm (23.09.2012); Berlin Declaration on Open Access to Knowledge in the Sciences and Humanities - vt http://oa.mpg.de/berlin-prozess/ berliner-erklarung/ (23.09.2012); OECD Principles and Guidelines for Access to Research Data from Public Funding. OECD, 2007 - vt http://www.oecd.org/science/scienceandtechnologypolicy/38500813.pdf (23.09.2012); Policy Statements on Data Management for Global Change Research. U.S. Global Change Research Program. Executive Office of the President, Office of Science and Technology Policy, Washington, D.C. 20506, July 2, 1991 - vt http://www. gcrio.org/USGCRP/DataPolicy.html (23.09.2012).
} 


\section{Autoriõigus kui litsentsimise õiguslik raamistik}

\subsection{Litsentsilepingu objekt ja subjekt keeleressursside puhul}

Keeleressursside litsentsimisel on vajalik määratleda litsentsilepingu objekt. Nagu eelnevalt öeldud, võib keeleressursid jagada laias laastus kaheks: keeleteaduslik andmestik ja tarkvara (vt ptk 2). Arvutiprogramm on autoriõiguslikult kaitstav kui kirjandusteos ning selle litsentsimisega seonduvaid küsimusi antud artiklis pikemalt ei käsitleta. Keeleteaduslik andmestik on samuti kaitstav autoriõigusega, kuid selle õigusliku olemuse täpsem avamine on komplitseeritum. Keeleteaduslikule andmestikule alljärgnevalt keskendutaksegi.

Autoriõigus on loodud kaitsma teose autori õigusi. Autoriõiguse seadus määratleb teosena originaalset tulemust kirjanduse, kunsti ja teaduse valdkonnas, mis on väljendatud objektiivses vormis (AutÕS $\S 4 \lg 2$ ). Teose ühe näitena nimetab autoriõiguse seadus ka andmebaase, mis kujutavad endast "süstemaatiliselt või metoodiliselt korrastatud iseseisvate teoste, andmete või muu materjali kogu, mis on individuaalselt kättesaadav elektrooniliste või muude vahendite abil" (AutÕS $\S 4 \lg 3 \mathrm{p} \mathrm{22).}$

Lisaks teosena kaitstavale andmebaasile, mis eeldavad autori loomingulist panust, kaitseb autoriõigus ka andmebaase, mille kaitstavuse seisukohalt ei ole oluline mitte autori loomingulisus, vaid selle valmimiseks tehtud investeering. ${ }^{31}$

Edaspidi nimetatakse selliseid andmebaase artiklis sui generis andmebaasideks (vt ka Tavast jt 2013 siinses kogumikus), sest nende suhtes on kehtestatud autoriõigusest erinev kaitserežiim. Suigeneris andmebaase määratletakse seaduses teoste, andmete või muu materjali süstemaatiliselt või metoodiliselt korraldatud koguna, mille kaitstavuse hindamise seisukohalt on oluline laadilt, väärtuselt või suuruselt olulise investeeringu tegemine selle andmebaasi sisuks olevate andmete kogumiseks, omandamiseks, kontrollimiseks, süstematiseerimiseks või kättesaadavaks tegemiseks (AutÕS $\S 75^{2}, 75^{3}$ ).

Eelneva pinnalt tekib küsimus, milline on keeleressursside õiguslik seisund? Artikli autorid on seisukohal, et keeleressursid on olemuselt andmebaasid, mis eeldavad reeglina loomingulist panust ${ }^{32}$, ning seetõttu kvalifitseeruvad need autoriõiguslikult kaitstavate teostena. Samas vajab keeleressursside loomine ka ulatuslikke investeeringuid, mistõttu põhimõtteliselt laieneb keeleressurssidele ka sui generis andmebaaside kaitse. Seega on keeleressursid kumulatiivselt kaitstavad nii autoriõiguslike teostena kaitstavate andmebaasidena kui ka sui generis andmebaasidena. ${ }^{33}$ Kuna teosena kaitstud andmebaas omab ulatuslikumat kaitset, siis reeglina ei teki sui generis kaitse järgi vajadust. Sui generis kaitse omab keeleressursside kontekstis tähtsust peamiselt siis, kui keeleressursside loomine eeldab ainult investeeringut, kuid mitte loovust.

Keeleressursside litsentsimise muudab keeruliseks olukord, kui ressursside loomisel kasutatakse autoriõiguslikult kaitstavaid tekste ning materjali, mille avaldamine võib olla vastuolus isikuandmete kaitse põhimõtetega. Kuna keeleressursside arendamise küsimusi on uuritud teistes artiklites ${ }^{34}$, siis siinkohal sellel pikemalt ei peatuta. Tuleb siiski välja tuua, et kui keeleressursid on loodud autoriõigusliku

\footnotetext{
31 Seadus räägib viimasel juhul just andmebaasi tegijast, mitte andmebaasi loojast. Vt AutÕS $\S 75^{3}$.

32 Loomingulisus võib väljenduda materjali valikus, mida andmabaasi sisestatakse.

33 Teatud juhtudel võib tõusetuda ka keeleressursside kaitse ärisaladusena. Ärisaladuse kaitse kohta vt Kelli jt 2010.

34 Vt Kelli jt 2012, Tavast jt 2013 (siinses kogumikus).
} 
teadustöö erandi raames (AutÕS $§ 19$ p 2 ja 3$)^{35}$ ilma litsentsilepinguta ning ka isikuandmeid on töödeldud isikuandmete kaitse seaduse teadusuuringu regulatsioonile (IKS § 16) tuginedes, siis ei saa taoliste ressursside kasutus väljuda teadusliku uurimistöö raamidest. Litsentsimisel on oluline lähtuda põhimõttest, et teistele ei saa anda rohkem õigusi kui need, mis endale kuuluvad. See ei tähenda, et ressursse ei saaks kasutada teised teadlased, kuid nende laiem levitamine on õiguslikult problemaatiline.

Samaväärselt oluline keeleressurssides sisalduva materjali õigusliku staatusega on ka keeleressursside kuuluvuse küsimus. Teiste sõnadega, kes on subjektiks litsentsilepingus, mille objektiks on keeleressursid? Keeleressursse on tavaliselt arendanud ülikooli või teadusasutuse töötajad. Autoriõiguse seaduse kohaselt töölepingu alusel oma otseste töö̈lesannete täitmise korras loodud teose autori varalised õigused lähevad üle tööandjale (AutÕS § $32 \lg$ 1), kuid tööandja ei saa automaatselt õigust kasutada töötaja isiklikke õigusi. Eelkõige on see oluline teose puutumatuse õiguse kontekstis, mis autori kui teose looja isikliku õigusena tähendab autori õigust teha ise või lubada teistel isikutel teha teoses muudatusi (AutÕS § $12 \lg 1$ p 3).

Teine probleemide ring võib tekkida asjaolust, et mitte kõik keeleressursside loojad ei ole olnud teadusasutuse koosseisulised töötajad. Osa tööd on tehtud töövõtulepingu alusel. Autoriõiguse seadus ei näe ette autori varaliste õiguste üleminekut töövõtulepingu raames. Sageli puuduvad sellistes lepingutes punktid autoriõiguse kuuluvuse kohta. Seetõttu on õiguslik olukord keerulisem, kuna ei ole selge, kas töövõtu alusel loodud ressursid kuuluvad teadusasutusele ja kas asutus saab neid edasi litsentsida. Samas tuleb antud probleemi puhul lähtuda ka lepinguõiguse üldistest põhimõtetest ning tõlgendada töövõtulepingut lähtudes poolte tahtest ja selle eesmärgist. Kui isiku ülesanne töövõtulepingu kohaselt oli keeleressursside arendamine, siis võib eeldada, et isik andis tellijale ka loa loodud keeleressursse kasutada.

\subsection{Litsentsitavad õigused}

Autoriõigusega kaitstavatele keeleressursside andmebaasidele laienevad autori isiklikud ja varalised õigused.

Üks kesksemaid isiklikke õigusi on õigus autorsusele (AutÕS § $12 \lg 1$ p 1), mida tuleb järgida nii keeleressursside loomisel kui ka kasutamisel. Samas võib praktikas tekkida probleeme juhul, kui teos avaldatakse tööandja nime all. Tööandja saab seda teha juhul, kui töölepingus on selgelt kokku lepitud isiklike õiguste teostamise osas. Keeleressursside, näiteks tekstikorpuste puhul ei ole siiani eriti rõhutatud nende seost ühe või teise isiku kui autoriga, kes loob teose, valides tekstimassiividest korpuse lingvistiliseks sisuks sobivad tekstid, lõigud, laused ja annoteerimisviisi. Teadustulemustes ja artiklites viidatakse praeguses praktikas korpustele enamasti tööandja (näiteks Tartu Ülikooli tasakaalus korpus ${ }^{36}$ ) või allüksusena uurimisrühma (näiteks TÜ suulise kõne uurimisrühma korpus ${ }^{37}$ ) kaudu. Kuna keeleressursid on oma olemuselt ka kollektiivsed teosed ${ }^{38}$, siis on taoline praktika õigustatud.

\footnotetext{
35 Autoriõiguse seadus ( $\$ 19$ p 2 ja 3) lubab kasutada autoriõiguslikult kaitstavaid teoseid ilma autori nõusolekuta ja autoritasu maksmiseta teaduslikel eesmärkidel. Vaatamata asjaolule, et teadustöö erand praegu kehtivas autoriõiguse seaduses saab olla aluseks keeleressursside loomisele, tuleks õigusselguse huvides kaaluda konkreetse

$36 \mathrm{Vt}$ http://www.cl.ut.ee/korpused/grammatikakorpus/ (22.12.2012).

$37 \mathrm{Vt}$ http://www.cl.ut.ee/suuline/Ylevaade (22.12.2012).

38 Autoriõiguse seaduse kohaselt "[k]ollektiivseks teoseks loetakse teost, mis koosneb erinevate autorite kaastöödest, mis on ühendatud ühtseks tervikuks füüsilise või juriidilise isiku poolt tema initsiatiivil ja juhtimisel ning mis antakse
} 
Keeleressursside litsentsimisel on isiklikest õigustest kõige suurema praktilise tähtsusega niinimetatud muutmisõigused: õigus teose puutumatusele ja õigus teose lisadele. Põhimõtteliselt lubab autoriõiguse seadus teost muuta vaid autori selgesõnalisel nõusolekul. Jälle on tööandja huvides see, et töölepingus oleks muutmisõiguste teostamise osas saavutatud eelnev kokkulepe. ${ }^{39}$

Keeleressursside loomisel ja kasutamisel saab kohaldada järgmisi autori varalisi õigusi: õigust teose reprodutseerimisele, õigust teose levitamisele, õigust teose tõlkimisele, õigust teose töötlemisele, õigust teoste kogumikele, õigust teose avalikule esitamisele, õigust eksponeerimisele, õigust teose edastamisele ja õigust teose üldsusele kättesaadavaks tegemisele (AutÕS § 13). Juba selle loetelu pikkus näitab, kuivõrd keeruliseks võib praktikas kujuneda andmebaasi kasutamine. Tööandja omandab selle paketi töötaja töökohustuste korras loodud teostele seaduse alusel (AutÕS § 32). Töövõtulepingus tuleks nende õiguste omandamises või kasutamises kokku leppida kas üksikute õiguste kaupa või nn paketina tervikuna - viimane on kasutajale soodsam ${ }^{40}$. Samas võib keeleressursside omaja olla ise valmis sõlmima litsentsilepinguid teiste kasutajatega just sellesama varaliste õiguste paketi piirides.

Litsentsimise juures kerkib veel üks oluline küsimus - milline on täienduste õiguslik staatus. Kui konkreetne keeleressurss ise on tehtud üldsusele vabalt kättesaadavaks, siis peaks litsentsilepingus nägema ette tingimuse, et ka selle täiendusi levitatakse samadel tingimustel. Kui keeleressursside omajal on huvi litsentsitavat ressurssi ka ise edasi arendada, siis võib leppida kokku, et litsentsisaaja kohustub litsentsiandjale omakorda andma loa tema poolt tehtud täienduste kasutamiseks.

\section{Võimalikud litsentsilepingute eeskujud keeleressursside litsentsimisel}

\subsection{Vabade (avatud) litsentside toimemehhanismid}

Sõltumata sellest, kas tegemist on koodi, muu sisu või andmebaaside jaoks mõeldud avatud litsentsidega, toimivad need üldjoontes ühtmoodi. Litsentsiandjaks on reeglina autor (või iga kaasautor või mõni muu autoriõiguste omaja) ja litsentsisaajaks teose või sui generis andmebaasi kasutaja. Kõik avatud litsentsid lubavad litsentsisaajal teost reprodutseerida ja oma tarbeks muuta ning muutmata koopiaid levitada. Avatud litsentsid võivad litsentsisaajale seada ka teatavaid kohustavaid tingimusi, millest levinuimad on

1) teose (või sellest tuletatud teoste ${ }^{41}$ ) levitamisel viitamine algsele autorile ja teosele ning

2) teose või sellest tuletatud teoste levitamine algse litsentsiga samadel või sarnastel tingimustel.

Tähelepanelik tuleb olla samadel tingimustel jagamise kohustust ('jagamine samadel tingimustel', ingl share-alike) sisaldava litsentsiga tähistatud materjalide

\footnotetext{
välja selle füüsilise või juriidilise isiku nime või nimetuse all (teatmeteosed, teaduslik kogumik, ajaleht, ajakiri ja teised perioodilised või jätkuväljaanded jms)" (AutÕS § $31 \lg 1$ ).

39 Käimasoleva intellektuaalse omandi reformi kontekstis on kaalumisel piirata autori isiklike õiguste ulatust viies muutmisõigused autori varaliste õiguste kataloogi. Täiendav info kättesaadav arvutivõrgus: https://ajaveeb.just.ee/ intellektuaalneomand/ (22.12.2012).

${ }^{40}$ Rõhutame, et esimesel juhul on töösuhte aluseks tööleping. Töövõtulepingu puhul on aga tegemist iseseisva tsiviilõigusliku lepingulise suhtega.

${ }^{41}$ Autoriõiguse seadus ( $\$ 4 \lg 3$ p 21) määratleb tuletatud teosena teose tõlget, algse teose kohandust (adaptsiooni), töötlust (arranžeeringut) ja teose muud töötlust. Minemata sügavuti tuletatud teose olemusse, võib öelda, et tuletatud teose loomine tähendab algteose vähemal või suuremal määral muutmist.
} 
kasutamisel. Sõltuvalt konkreetse litsentsi tingimuste sõnastusest võib see tingimus nõuda litsentsitud teosest tuletatud teoste levitamisel täpselt sama litsentsi kasutamist. See tähendab, et juhul, kui loodav teos on tuletatud teoseks mitme erinevate "jagamine samadel tingimustel"-nõuet sisaldava litsentsi alusel levitatava komponentteose suhtes, ei pruugi uue teose levitamine olla võimalik ilma ühe või enama komponentteose autoriõiguste valdajailt selleks eraldi loa saamist.

Mõned teose reprodutseerimist ja levitamist lubavad litsentsid võivad piirata ka litsentsitava teose kasutusviise (nt lubades selle kasutamist ainult mitteärilisel eesmärgil või keelates sellest tuletatud teoste levitamist) või kasutajaskonda (nt lubades teose ja sellest tuletatud teoste koopiate levitamist ainult kindlaksmääratud kogukonna piires nagu META-SHARE Commons litsentsid ${ }^{42}$ ). Tõsi, sellisel juhul ei ole enam tegemist vabade (avatud) litsentsidega Free Software Definition'i ${ }^{43}$, Open Source Definition’i ${ }^{44}$ ega Open Definition'i ${ }^{45}$ mõttes.

\subsection{META-SHARE ja CLARIN võrgustikud ja nendes kasutatavad litsentsid}

Mitmekeelses Euroopas on kaks suuremat algatust, mis püüavad koguda ja teha kättesaadavaks paljude Euroopa keelte keeleressursse: META-NET ${ }^{46}$ ja CLARIN 47 .

META-NET on kujundanud keeleressursside litsentsimiseks põhjaliku poliitika ja avalikustanud oma veebiportaalis üksikasjaliku ülevaate, miks ja millised litsentsid on välja töötatud ${ }^{48}$. Tartu Ülikool osaleb selles algatuses projekti METANORD $^{49}$ kaudu ja on kohustatud seetõttu töös hoidma META-SHARE50 registrit ja repositooriumi (nn võrgustikusõlme ehk node’i kujul), milles hoitakse ka Eesti keeleressursse. Registris hoitakse ressursside kirjeldusi ehk metaandmeid ja repositooriumis ressursse endid. Metaandmete hulka kuulub ka teave ressursi omaniku kohta, omaniku nõusolek (ingl Depositor's Agreement) ressurssi võrgustiku sõlme kaudu jagada ning erinevatele kasutajatele mõeldud kasutusõigused vastavate litsentside kujul.

META-SHARE üldine poliitika nõuab, et repositooriumis kättesaadavaks võib teha vaid neid ressursse, mille kasutusõigused on selged ning puuduvad autoriõiguslikud või isikuandmete kaitsest tulenevad piirangud. Sellepärast on vajalik saavutada juba kasutusel olevate ja mitmel pool veebi kaudu kättesaadavate keeleressursside litsentsimine.

META-SHARE lähenemine sarnaneb CC omale: litsentsiandja ei ole litsentsitingimuste valikul täiesti vaba, vaid peab valima olemasolevate tüüplitsentside hulgast talle sobivaima. Valida on kolme tüüpi litsentside vahel:

1) CC litsentsid: võimalusel $\mathrm{CCo}$, vajadusel koos täiendavate piirangutega (autorile viitamise või "jagamine samadel tingimustel” kohustus; ärilise kasutuse või tuletatud teoste levitamise keeld);

2) META-SHARE Commons litsentsid (lubavad levitamist META-SHARE võrgustiku siseselt; piirangute valik on sarnane CC litsentsidega);

${ }^{42} \mathrm{Vt}$ http://www.meta-net.eu/meta-share/licenses (21.12.2012).

${ }^{43}$ Free Software Definition http://www.gnu.org/philosophy/free-sw.html (21.12.2012).

${ }^{44}$ Open Source Definition http://opensource.org/docs/osd (21.12.2012).

45 Open Definition http://opendefinition.org (21.12.2012).

46 META-NET http://www.meta-net.eu/ (21.12.2012).

47 CLARIN http://www.clarin.eu/ (21.12.2012).

$48 \mathrm{Vt}$ http://www.meta-net.eu/meta-share/licenses (21.12.2012).

49 META-NORD http://www.meta-nord.eu/ (21.12.2012).

50 META-SHARE http://www.meta-net.eu/meta-share/index html-et?set language=et (21.12.2012). 
3) META-SHARE NoRedistribution litsentsid (keelavad litsentsitavate teoste modifitseerimata koopiate levitamise, muud piirangud on sarnased CC litsentsidega).

META-NETi omanikuleppe kohta (ingl Depositor's Agreement, DA) on Eesti keeleteadlastel juba üks positiivne näide olemas. META-NORDi projekti raames pidid kõik osalevad keeled looma puudepanga (vt keeleressursside liigitust ptk 2 alapunkt c) ja et kõikide osalevate keelte puudepangad oleks võrreldavad, kasutati puudepangas analüüsiks üht ja sama teksti, Norra kirjaniku Jostein Gaarderi teose "Sophie maailm" esimese peatüki lauseid. Seega oli vaja saada DA mitte ainult originaalkeeles teosele, vaid ka selle kõikidele tõlgetele.

CLARINit ehk üldist keeleressursside ja -tehnoloogia infrastruktuuri ettevalmistavas projektis tegeldi samuti keeleressursside õiguslike teemadega ja selle kohta valmis raport. ${ }^{51}$ Raporti koostajad, Helsingi ülikooli keeleteadlased, on hiljem koostöös juristidega avaldanud samal teemal ka artikleid (Oksanen jt 2010, Oksanen, Lindén 2011) keeletehnoloogia ja -ressursside konverentsidel, kus keeleressursside õiguslikud aspektid tekitavad viimastel aastatel väga elavat huvi.

Eestil CLARIN ERICu asutajaliikmena on kohustus järgida ERICu põhikirjas ${ }^{2}$ märgitud raamtingimusi ligipääsu, intellektuaalomandi ja litsentsimise osas. Eesti Keeleressursside Keskusel kui CLARIN ERICu riiklikul konsortsiumil on kohustus hallata keeleressursse ka kui intellektuaalset omandit ja järgida seejuures CLARIN ERICu raamtingimusi.

CLARINis kasutatakse uute ressursside litsentsimisel standardiseeritud tüüplepingut, mis sisaldab rida erinevaid valikulisi tingimusi, mille hulgast litsentsiandja valib endale sobivad. Olemasolevate ressursside litsentside klassifitseerimiseks on CLARINi jaoks välja töötatud nn "pesumärkide" süsteem (Oksanen, Lindén 2012), mille peamine eesmärk on hõlbustada ressursside kasutajail ülevaate saamist olulistest litsentsitingimustest. Pesumärkidega tähistatakse esmalt iga ressursi maksimaalne leviala (PUB - avalik, ACA - akadeemiline, RES - piiratud) ning täiendavate tähistega null kuni kolm lisapiirangut (NC - ärilise kasutuse keeld, INF - kohustus informeerida ressursi autoriõiguste omajat selle kasutamisest publitseeritud artiklites, ReD - kohustus ressursi modifitseeritud versioonid CLARINi repositooriumisse laadida).

Sarnaselt META-SHAREiga soovitatakse ka CLARINis litsentsida sinna lisatavaid uusi keeleressursse nii väheste piirangutega kui võimalik, tagamaks nende vaba kasutatavus vähemalt vastava võrgustiku piires. Mõlemas võrgustikus on esimeseks eelistuseks CCo.

\section{Järeldused ja ettepanekud}

Mida vabamalt saab kasutada avalike vahendite baasil loodud keeleressursse ja -tehnoloogiaid, seda parem eesti keelele, kultuurile ja rahvale. Avatud juurdepääsu põhimõtteid tuleks laiendada kõigile avalikest vahenditest finantseeritud teadustulemuste vormidele ja kasutusviisidele keeleressursside kontekstis.

Võimalusel on soovitatav valida keeleressursside- ja tehnoloogiate levitamiseks litsentsid, mis toetavad avatud juurdepääsu põhimõtteid. Erinevate litsentside

\footnotetext{
51 A report including Model Licensing Templates and Authorization and Authentication Scheme. Vt http://www-sk. let.uu.nl/u/D7S-2.1.pdf (21.12.2012).

52 ET 3.3.2012 Euroopa Liidu Teataja L 64, vt art 2.2 (g), art 19, $22,25$.
} 
kasutamisel tuleb arvestada võimalike ühildumisprobleemidega. Lihtsaim võimalus ületada ühildumisprobleeme on valida litsents, mis kõrvaldab kõige enam autori ainuõigustest tulenevaid piiranguid, lubades muuhulgas ärilisel otstarbel kasutamist avalikes huvides oleval eesmärgil ning kohustades seejuures üksnes autorile viitama. Selleks sobiksid näiteks Creative Commons autorile viitamise kohustusega (CC BY) või CCo, millega keeleressurss antaks üldiseks kasutamiseks.

Keeleressursside litsentsimisel on oluline arvestada nii andmebaasi, selle sisu kui ka selle kasutamiseks vajalike arvutiprogrammide õigusliku režiimiga. Samuti on tähtis, et kõigi isikutega, kes keeleressursside loomisesse panustavad, oleksid sõlmitud korrektsed lepingud.

Asjaolu, mis võib ulatuslikult kitsendada keeleressursside (eelkõige korpuste) litsentsimise võimalusi avatud juurdepääsu põhimõtete kohaselt, on see, kui nende loomiseks vajalikke teoseid kasutati tuginedes autoriõiguse teose vaba kasutamise eranditele. Sellisel juhul peab ka kasutus piirduma teadustöö eesmärkidega.

Litsentsiraamistiku kujundamisel Eesti keeleressursside jaoks tuleb arvestada rahvusvahelise dimensiooniga. Vajalik oleks võtta kasutusele litsentsiraamistik, mis tagab Eesti keeleressursside kasutustingimuste ühildumise rahvusvahelises kontekstis. Seetõttu ei ole otstarbekas töötada välja Eesti-spetsiifilisi tüüptingimusi, vaid soovitav on valida juba olemasolevate litsentside vahel. Praeguses seisus tunduvad olevat kõige sobilikumad Creative Commons’i litsentsid. Täiendavalt tuleks koostada keeleressursside loojate jaoks praktiline juhend, milliseid litsentsitüüpe konkreetsel juhul kasutada.

\section{Viidatud kirjandus}

AutÕS = Autoriõiguse seadus. RT I 1992, 49, 615 ... RT I, 28.12.2011, 1.

IKS = Isikuandmete kaitse seadus. RT I 2007, 24, 127 ... RT I, 30.12.2010, 2.

Kelli, Aleksei; Mets, Tõnis; Pisuke, Heiki; Vasamäe, Elise; Värv, Age 2010. Trade secrets in entrepreneurs' intellectual property strategies: The Estonian experience. - Review of Central and East European Law, 35 (4), 315-339. http://dx.doi.org/10.1163/157303 $510 X 12650378240476$

Kelli, Aleksei; Tavast, Arvi; Pisuke, Heiki 2012. Copyright and Constitutional aspects of digital language resources: The Estonian approach. - Juridica International, 19, 40-48.

Kreutzer, T. 2011. User-related assets and drawbacks of open content licensing. - L. Guibault, C. Angelopoulos (Eds.). Open Content Licensing: From Theory to Practice. Amsterdam University Press.

Liin, Krista; Muischnek, Kadri; Müürisep, Kaili; Vider, Kadri 2012. Eesti keel digiajastul. META-NET Valge raamatu sari. Toim: Hans Uszkoreit, Georg Rehm. Springer. http:// www.meta-net.eu/whitepapers/volumes/estonian (23.09.2012).

Mõtsküla, Peeter P. 2009. Vaba tarkvara litsentside süstemaatiline analüüs. Magistritöö. Tartu Ülikooli õigusteaduskond.

Oksanen, Ville; Lindén, Krister; Westerlund, Hanna 2010. Laundry symbols and license management: Practical considerations for the distribution of LRs based on experiences from CLARIN. - Proceedings of LREC 2010: Workshop on Language Resources: From Storyboard to Sustainability and LR Lifecycle Management. https://helda.helsinki.fi/ bitstream/handle/10138/29359/LREC2010.pdf?sequence=2 (21.12.2012).

Oksanen, Ville; Lindén, Krister 2011. Open Content Licenses: How to choose the right one. - Workshop on Visibility and Availability of LT Resources, NODALIDA 2011. 
https://helda.helsinki.fi/bitstream/handle/10138/29355/Open_Content_Licenses. pdf? sequence $=2$ (21.12.2012).

Oksanen, Ville; Lindén, Krister 2012. Building shared language research environments inside European Union - how to optimize the system based on experiences from real life. Presented at The 1st Global Thematic IASC Conference on the Knowledge Commons. http://biogov.uclouvain.be/iasc/doc/full papers/Ville-Linden.pdf (21.12.2012).

Pisuke, Heiki; Kelli, Aleksei 2007. Some issues regarding entrepreneurial universities and intellectual property. - Juridica International 12, 161-172.

Tavast, Arvi; Kelli, Aleksei; Pisuke, Heiki 2013. Õiguslikud väljakutsed ja võimalikud lahendused keeleressursside arendamisel. - Eesti Rakenduslingvistika Ühingu aastaraamat, 9, 317-332. http://dx.doi.org/10.5128/ERYa9.20

Tuulik, Triin 2012. Avatud juurdepääsu kontseptsiooni mõned õiguslikud aspektid. - Juridica, VII, 522-528.

VõS = Võlaõigusseadus. RT I 2001, 81, 487 ... RT I, 08.07.2011, 6.

CLARIN ERIC põhikiri. ET 3.3.2012 Euroopa Liidu Teataja L 64. http://www-sk.let.uu.nl/u/ D8S-5a.pdf (14.12.2012).

\section{Võrgumaterjalid}

Avatud juurdepääsu määratlusi. Open Knowledge Foundation’i Open Definition. http:// opendefinition.org (21.12.2012); Vabade Kultuuriliste Teoste Definitsioon. Definition of Free Cultural Works. http://freedomdefined.org (21.12.2012).

CLARIN http://www.clarin.eu/ (21.12.2012).

CLARIN ERICu põhikiri. ET 3.3.2012 Euroopa Liidu Teataja L 64. http://www-sk.let.uu.nl/u/ D8S-5a.pdf (14.12.2012).

CLARINi õigusasjade raport. (A report including Model Licensing Templates and Authorization and Authentication Scheme.) http://www-sk.let.uu.nl/u/D7S-2.1.pdf (21.12.2012).

Creative Commons http://creativecommons.org (21.12.2012).

CC Eesti http://creativecommons.ee (21.12.2012).

CCo. http://creativecommons.org/choose/zero/ (21.12.2012).

EKT riikliku programmi tekst http://www.keeletehnoloogia.ee/EKT2011-2017-programmuuendet.pdf (14.12.2012).

EUPL http://ec.europa.eu/idabc/servlets/Doc3cb1.pdf?id=29923 (22.12.2012); http:// ec.europa.eu/idabc/en/document/7774.html (23.12.2012).

Free Software Definition http://www.gnu.org/philosophy/free-sw.html (14.12.2012).

META-NET http://www.meta-net.eu/ (21.12.2012).

META-NET pressiteade http://www.meta-net.eu/whitepapers/press-release-et (23.09.2012).

META-NORD http://www.meta-nord.eu/ (21.12.2012).

META-SHARE http://www.meta-net.eu/meta-share/index html-et?set language=et (21.12.2012).

META-SHARE Commons litsentsid http://www.meta-net.eu/meta-share/licenses (21.12.2012).

META-SHARE harta http://www.meta-net.eu/meta-share/METASHARE Charter.pdf (14.12.2012).

ODC PDDL http://opendatacommons.org/licenses/pddl/ (21.12.2012).

Open Data Commons http://opendatacommons.org (21.12.2012).

Open Source Definition http://opensource.org/docs/osd (21.12.2012).

Open Source Software http://opensource.org (14.12.2012).

Riiklik programm "Eesti keele keeletehnoloogiline tugi 2006-2010" (EKKTT) http://www. keeletehnoloogia.ee/ekktt-1 (14.12.2012).

Riiklik programm "Eesti keeletehnoloogia 2011-2017" (EKT) http://www.keeletehnoloogia.ee (14.12.2012). 
Tartu Ülikooli tasakaalus korpus http://www.cl.ut.ee/korpused/grammatikakorpus/ (22.12.2012).

Tartu Ülikooli suulise kõne uurimisrühma korpus http://www.cl.ut.ee/suuline/Ylevaade (22.12.2012).

Tartu Ülikooli intellektuaalomandi kord http://www.ut.ee/sites/default/files/livelink files/intellektuaalse omandi ksitlemise phimtted tartu likoolis terviktekst.pdf (23.09.2012).

Tallinna Ülikooli intellektuaalomandi kord http://www.tlu.ee/files/arts/314/intel2e2435b4d99b60a2481cd7c54d2f93a7.pdf (23.09.2012).

Vaba tarkvara litsentsid http://www.gnu.org/licenses/license-list.html (21.12.2012); http:// opensource.org/licenses (21.12.2012).

Kadri Vider (Eesti Keeleressursside Keskus, Tartu Ülikool), üks uurimissuundi on keeletehnoloogiliste ressursside ja tarkvara haldamine, kättesaadavaks tegemine ning litsentsimine või sellealane konsulteerimine.

kadri.vider@ut.ee

Heiki Pisuke (Euroopa Liidu Nõukogu, Tartu Ülikool), põhilised uurimissuunad on intellektuaalne omand (autoriõigus ja autoriõigusega kaasnevad õigused), tõlkimise õiguslikud küsimused, ülikoolide intellektuaalse omandi küsimused.

heiki.pisuke@ut.ee

Peeter P. Mõtsküla (Tartu Ülikool), põhilised uurimissuunad on intellektuaalne omand, autoriõigus (eriti tarkvara õiguskaitse) ning litsentsimine.

peeterpaul@motskula.net

Triin Tuulik (Tartu Ülikool), põhilised uurimissuunad on intellektuaalne omand (eriti looja-keskne intellektuaalomand ettevõtjate perspektiivist).

tuultriinik@gmail.com

Aleksei Kelli (Tartu Ülikool) põhilised uurimissuunad on intellektuaalne omand, innovatsioon, teadmistepõhine majandus, digitaalsete keeleressursside õiguslikud küsimused.

aleksei.kelli@ut.ee 


\title{
LEGAL CONSIDERATIONS \\ IN LICENSING LANGUAGE RESOURCES
}

\author{
Kadri Vider ${ }^{1,2}$, Heiki Pisuke ${ }^{3,2}$, Peeter P. Mõtsküla ${ }^{2}$, \\ Triin Tuulik ${ }^{2}$, Aleksei Kelli ${ }^{2}$ \\ Center of Estonian Language Resources' ${ }^{1}$, University of Tartu' ${ }^{2}$, Council of the European Union ${ }^{3}$
}

The purpose of this article is to present the underlying legal considerations for licensing language resources. The authors concentrate on analysing language resources in the form of data bases, addressing the complex legal issues concerning copyright and related rights. Different frameworks for licensing language resources, such as META-NET, CLARIN and Creative Commons standard licences, are explained and compared in the context of Open Access.

The article has been written in cooperation between linguists and lawyers and is practically oriented. Its purpose is to address the scholars and scholarly institutions associated with Estonian language resources and explain the fundamental principles of licensing objects of intellectual property. The authors highlight risks and problems, which can become serious obstacles, when combining and processing several language resources, each subjected to a different licence regime.

The article provides an overview of the current situation regarding licensing of language resources in Estonia, establishes the main legal characteristics of the data base as an object of intellectual property rights, and offers guidance regarding the selection of a suitable set of standard rules for licensing such data bases.

Keywords: human language resources, language technology, copyright, licensing, open access, META-SHARE, CLARIN 